Available online at http://jurnal.goretanpena.com/index.php/JSSR

\title{
APLIKASI METODE QUALITY FUNCTION DEPLOYMENT UNTUK SISTEM PENINGKATAN PELAYANAN KONSUMEN
}

\author{
Fahmi Kurniawan ${ }^{1}$, Zulham Sitorus ${ }^{2}$, Said Oktaviandi ${ }^{3}$ \\ Universitas Pembangunan Panca Budi, Medan \\ e-mail: fahmikurniawan@dosen.pancabudi.ic.id
}

\begin{abstract}
Service is the most important thing in providing comfort to customers. Loyalty to consumers is characterized by consumers who continuously want to use the services of a company. In addition to knowing the level of service that already exists, and knowing the difference between existing conditions and consumer expectations, it is necessary to make efforts to improve service quality in accordance with consumer expectations. The service sector is a sector that contributes a lot to the economic growth sector. Improved customer service is one of the factors of the success of the service industry. In the management system, the company feels the need to improve service quality to retain customers at PT. the Telkom Ases. The application of the QFD (Quality Function Deployment) method is a method that brings a service system to be the largest in Asia and the world. The QFD method has been widely used in various fields of research and decision-making systems. QFD is a research based on how the voice of consumers is translated into technical aspects that support its implementation in the field. In this study the QFD method is used in the customer service improvement system.
\end{abstract}

Keywords: Consumer, QFD (Quality Function Deployment), Service.

\begin{abstract}
Abstrak: Pelayanan merupakan hal terpenting dalam memberikan kenyamanan terhadap pelanggan. Loyalitas kepada konsumen ditandai dengan konsumen yang terus menerus mau menggunakan jasa dari suatu perusahaan. Selain mengetahui tingkat layanan yang sudah ada, dan mengetahui adanya perbedaan antara kondisi yang ada dengan harapan konsumen maka perlu dilakukan usaha untuk meningkatkan kualitas layanan sesuai dengan harapan konsumen. Sektor jasa adalah sektor yang banyak bekontribusi pada sektor pertumbuhan ekonomi. Peningkatan layanan konsumen adalah salah satu faktor dari keberhasilan industri jasa. Pada sistem manajemen perusahaan merasa perlu melakukan peningkatan kualitas layanan untuk mempertahankan konsumen yang ada di PT. Telkom Ases tersebut. Aplikasi metode QFD (Quality Function Deployment) adalah sebuah metode yang membawa sebuah system pelayanan menjadi terbesar di Asia dan dunia. Metode QFD telah luas digunakan diberbagai bidang penelitian dan sistem pengambilan keputusan. QFD merupakan penelitian yang didasarkan bagaimana suara konsumen diterjemahkan kepada aspek-aspek teknis yang menunjang pelaksanaannya di lapangan. Dalam penelitian ini metode QFD digunakan dalam sistem peningkatan layanan konsumen.
\end{abstract}

Kata kunci: Konsumen, QFD (Quality Function Deployment), Pelayanan.

\section{PENDAHULUAN}

Saat ini perkembangan sektor jasa semakin meningkat, kontribusi sektor ini terhadap pertumbuhan ekonomi tidak kalah dibandingkan dengan sektor lainnya. Oleh karena itu tingkat kualitas sistem pelayanan industri jasa harus selalu ditingkatkan. Cara yang dapat ditempuh adalah dengan berusaha untuk mengetahui dan memahami ekspektasi dan persepsi pelanggan terhadap sistem pelayanan yang diberikan. Dengan demikian, pihak penyedia jasa dapat memperbaiki sistem pelayanannya, dan berdasarkan pengetahuan tentang karakteristik pelanggan, maka dapat dirancang dan 
Available online at http://jurnal.goretanpena.com/index.php/JSSR

dikembangkan sistem pelayanan yang lebih baik.

PT. Telkom Akses Medan memberikan Loyalitas kepada konsumen menjadi hal yang sangat penting bagi sebuah Telkom Akses untuk tetap bisa bertahan. Loyalitas kepada konsumen ditandai dengan konsumen yang terus menerus mau menggunakan jasa Telkom Akses tersebut. Deng, Kuo, dan Wu (2009) mengatakan bahwa kualitas layanan berpengaruh positif terhadap postpurchase intention dengan customer satisfaction sebagai variabel perantaranya. Lebih jelasnya berarti kualitas layanan yang baik akan meningkatkan kepuasan konsumen yang pada akhirnya akan meningkatkan loyalitas kepada konsumen suatu perusahaan menginginkan loyalitas itu dimiliki oleh perusahaan kepada konsumennya oleh karena itu, sebuah perusahaan harus dapat memuaskan konsumennya, yaitu dengan memberikan pelayanan yang terbaik.

Metode QFD telah digunakan oleh banyak perusahaan Jepang untuk mencari input tentang bagaimana desain yang cocok dan disukai oleh konsumen yang menggunakan produk-produk perusahaan tersebut. Di Indonesia sendiri perusahaan Jepang yang antara lain: Toyota, Mitsubishi, dan Honda dapat dengan sukses merajai industry otomotif Indonesia. Metode QFD dapat digunakan untuk meningkatkan kinerja melalui perbaikan sistem yang berjalan.

Penelitian terdahulu adalah upaya peneliti untuk mencari perbandingan dan selanjutnya untuk menemukan inspirasi baru untuk penelitian selanjutnya di samping itu kajian terdahulu membantu penelitian dalam memposisikan penelitian serta menunjukkan orsinalitas dari penelitian. Peneliti mencantumkan berbagai hasil penelitian terdahulu yang terkait dengan penelitian yang hendak dilakukan. Kajian yang mempunyai relasi atau keterkaitan dengan kajian ini antara lain:

1. Indra Kanedi, dkk yang berjudul Sistem Sistem Pelayanan Untuk Penngkatan Kepuasan Pengunjung
Pada Perpustakaan Arsip Dan Dokumentasi Kota Bengkulu. Mendeskripsikan Tingkat mutu pelayanan merupakan penunjang utama dalam peningkatan pengujung perpustakaan, dan dengan adanya sistem pelayanan ini dapat menambah mutu dalam layanan serta pendataan lebih akurat dan terjaga kerahasiaan datanya.

2. Ahmad Fauzi, yang berjudul Peningkatan Kualitas Pelayanan Melalui CRM dengan Metode RAD Membahas tentang cara efisiensi pelayanan dengan Persaingan usaha tidak hanya berlaku pada bagaimana cara memperoleh pelanggan sebanyak mungkin, namun sekarang ini persaingan usaha juga berupa bagaimana mempertahankan pelanggan dan memberikan kepuasan terhadap pelanggan sehingga pelanggan merasa dilayani sebagai raja. Customer Relationship Management merupakan salah satu cara dalam menjaga dan meningkatkan kualitas pelayanan kepada pelanggan, kesulitankesulitan dalam memahami dan menganalisis kebutuhan pelanggan dapat dilakukan dengan membangun CRM yang baik. Metode Rapid Application Development dapat memberikan kecepatan dan efisiensi dalam membangun CRM. Hasil penelitian menunjukan bahwa dengan menggunakan metode RAD, proses pembangunan sistem CRM menjadi lebih cepat dan sesuai dengan kebutuhan pelaku usaha. Selain itu dengan adanya CRM, tingkat kepuasan pelanggan meningkat hingga $85 \%$ dan memudahkan pelaku usaha dalam menjalankan usahanya.

Adapun permasalahan yang dihadapi dalam memberikan pelayanan terbaik terhadap konsumen adalah:

1. Faktor dalam mengidentifikasi keluhan-keluhan yang berasal dari konsumen yang merasa tidak puas 
Available online at http://jurnal.goretanpena.com/index.php/JSSR

atas layanan yang telah diberikan oleh pihak PT. Telkom Ases Medan.

2. Keptusan untuk mengetahui faktor apa saja yang menjadi penyebab dari ketidak puasan konsumen atas pelayanan.

3. Merumuskan sistem perbaikan terhadap faktor-faktor yang menjadi masalah tersebut.

Dalam membangun Aplikasi Metode Quality Function Deployment Untuk Sistem Peningkatan Pelayanan Konsumen untuk tepat sasaran, maka diberikan batasan masalah yaitu konsumen yang dimaksud pada penelitian adalah konsumen pribadi yang datang sendiri ke PT. Telkom Akses Medan dan sebatas sampai pemberian usulan perbaikan peningkatan layanan kualitas dan tidak melakukan pengukuran setelah usulan tersebut dilaksanakan atau diimplementasikan.

Tujuan yang ingin dicapai dalam membangun Aplikasi Metode Quality Function Deployment Untuk Sistem Peningkatan Pelayanan Konsumen ini adalah :

1. Mengetahui kriteria konsumen dan teknis apa saja untuk usaha peningkatan pelayanan perusahaan.

2. Membuat sebuah sistem peningkatanan pelayanan dengan bantuan aplikasi komputer.

3. Menerapkan metode QFD (Quality Function Deployment) pada sistem peningkatan layanan konsumen.

Merancang Aplikasi Metode Quality Function Deployment untuk Sistem Peningkatan Pelayanan Konsumen ini diharapkan bisa memberi manfaat bagi perusahaan antara lain:

1. Membantu perusahaan dalam mengetahui tingkat kepuasan konsumennya.

2. Membantu perusahaan dalam upaya peningkatan kualitas pelayanan konsumen.

3. Mengetahui elemen layanan yang paling bermasalah untuk ditingkatkan dan upaya untuk peningkatan kualitas layanan yang lebih baik.

\section{METODE}

Metode pengumpulan data yang digunakan dalam penelitian ini adalah metode deskriptif. Adapun teknik pengumpulan data dilakukan dengan cara sebagai berikut:

Masalah dilakukan dalam pengamatan pengumpulan data yang dilakukan dengan mengamatin secara langsung objek yang diteliti sehingga data yang didapat adalah data tingkat pelayanan konsumen.

Pengumpulan data dengan menggunakan atau mengumpulkan sumber-sumber tertulis, dengan cara membaca, mempelajari dan mencatat halhal penting yang berhubungan dengan masalah yang sedang dibahas guna memperoleh gambaran secara teoritis.

\section{Metode Pengembangan}

Perangkat Lunak Metodelogi yang digunakan untuk membangun sistem ini adalah Model Waterfall. Model ini terdiri dari beberapa tahapan, yaitu: System Engineering, Analysis, Design, Coding, Testing dan Maintenance.

\section{HASIL DAN PEMBAHASAN}

Dalam perancangan aplikasi Metode Quality Function Deployment Untuk Sistem Peningkatan Pelayanan Konsumen, penulis menggunakan program aplikasi yang berbasis desktop dengan matlab sebagai bahasa pemrogramannya. Program yang di buat dengan menerapkan Metode Quality Function Deployment dan dirancang denan tampilan yang mudah untuk digunakan, pengguna hanya mamasukan nilai skala kenaikan, poin peningkatan pelayanan dan nilai hubungan dan aplikasi akan memberikan hasil penilaian pelayanan. Tahapan implementasi yang dilakukan untuk menyelesaikan perancangan aplikasi Metode Quality Function Deployment Untuk Sistem Peningkatan Pelayanan Konsumen ini diperlukan informasi mengenai penyediaan perangkat keras (Hardware) dan perangkat lunak (Software). 
Available online at http://jurnal.goretanpena.com/index.php/JSSR

Tampilan Aplikasi Peningkatan

Pelayanan Konsumen

Tampilan aplikasi Peningkatan Pelayanan Konsumen ini terdiri dari tampilan menu utama yang didalamnya ada terdapat tombol Persayaratan Konsumen \& Persayaratan Teknis, tombol hubungan persayaratan konsumen $\&$ teknis, tombol hasil prioritas konsumen \& teknis dan tombil keluar. Adapun tampilan menu utama aplikasi Peningkatan Pelayanan Konsumen ini adalah sebagai berikut :

Tampilan Menu Utama

Tampilan menu utama terdiri Persayaratan Konsumen \& Persayaratan Teknis, hubungan persayaratan konsumen $\&$ teknis, tombol hasil prioritas konsumen $\&$ teknis dan keluar.

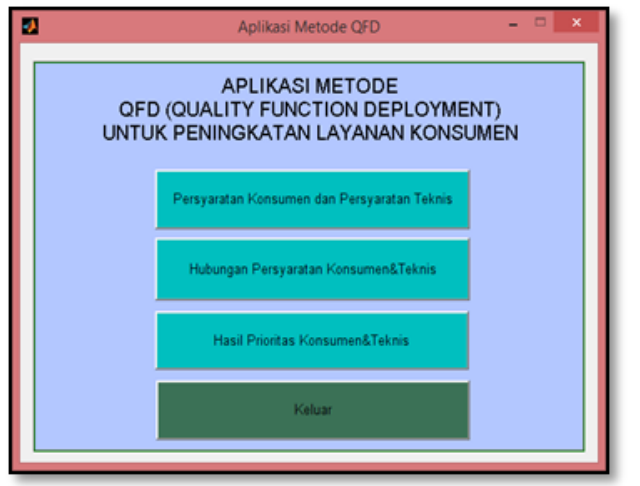

Gambar Tampilan Menu Utama

Berikut fungsi dari 4 tombol yang ada pada menu utama:

1. Tombol persyaratan konsumen dan persyaratan teknis berfungsi untuk menampilkan form input nilai skala kenaikan, poin peningkatan pelayanan dan nilai hubungan.

2. Tombol hubungan persyaratan konsumen dan teksnis berfungsi untuk menampilkan form untuk melakukan proses perhitungan metode QFD.

3. Tombol Hasil Penilaian Konsumen dan teknis berfungsi untuk menampilkan form hasil perhitungan dari metode QFD.

4. Tombol Keluar berfungsi untuk menutup program aplikasi
Tampilan Persyaratan Konsumen dan Teknis

Tampilan persyaratan konsumen dan teknis merupakan form yang digunakan untuk melakukan penginputan nilai nilai skala kenaikan, poin peningkatan pelayanan dan nilai hubungan.

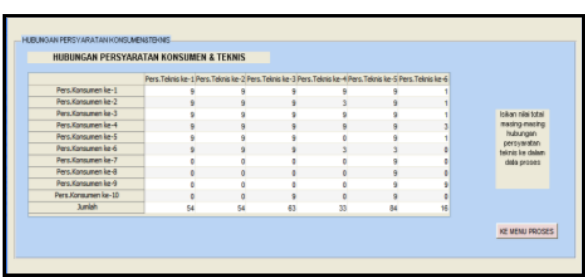

Gambar. Tampilan Persyaratan Konsumen dan Teknis

Tampilan Hubungan Persyaratan Konsumen dan Teknis

Tampilan hubungan persyaratan konsumen dan teknis merupakan tampilan form yang digunakan untuk melakukan proses perhitungan metode QFD didalam penilaian pelayanan .

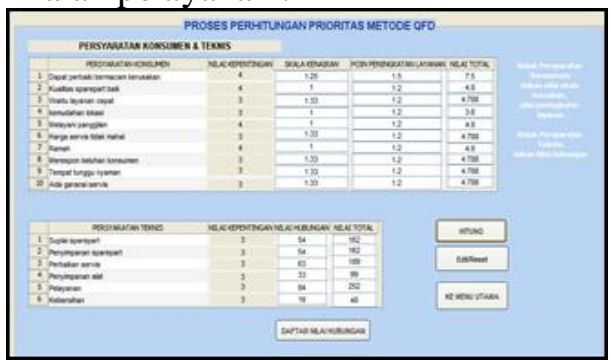

Gambar. Tampilan Hubungan Persyaratan Konsumen dan Teksnis

Tampilan Hasil Prioritas Konsumen dan Teknis

Tampilan hasil prioritas konsumen dan teknis merupakan tampilan form yang digunakan untuk melihat hasil perhitungan metode QFD didalam penilaian pelayanan .

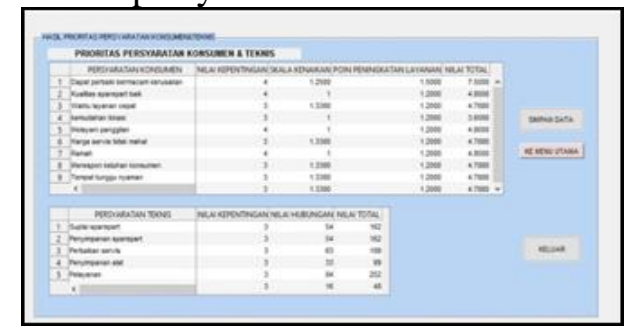

Gambar.Tampilan Hasil Prioritas

Konsumen dan Teksnis 
Available online at http://jurnal.goretanpena.com/index.php/JSSR

Pengujian Aplikasi Sistem Peningkatan Pelayanan Konsumen

Pengujian aplikasi Sistem Peningkatan Pelayanan Konsumen ini digunakan untuk menguji sistem pada salah satu menu dimana data yang digunakan adalah proses melakukan perhitungan metode QFD berdasarkan data yang diinputkan yaitu nilai nilai skala kenaikan, poin peningkatan pelayanan dan nilai hubungan. Cara menggunakan aplikasi Sistem Peningkatan Pelayanan Konsumen adalah sebagai berikut:

1. Langkah awalnya user menjalankan aplikasi dan akan tampil menu utama.

2. Kemudian user melakukan klik pada tombol persyaratan konsumen dan teknis untuk menginputkan nilai skala kenaikan, poin peningkatan pelayanan dan nilai hubungan.

3. Setelah diinputkan dan untuk memproses nilai tersebut user mengklik tombol hubungan konsumen dan teknis.

4. Maka, kemudian akan muncul form dan pada form tersebut nantinya ada tombol hitung yang digunakan untuk melakukan perhitungan metode QFD.

5. Untuk melihat hasil perhitungan user dapat mengklik menu hasil prioritas konsumen dan teknis.

\section{SIMPULAN}

Mengidentifikasi keluhan konsumen adalah menggali informasi dari konsumen dengan obsevasi langsung terhadap konsumen, sehingga didapatkan aspek apa saja dikehendaki oleh konsumen yang mengeluhkan pelayanan pada perusahaan.

Mengetahui faktor yang menjadi penyebab ketidakpuasan konsumen adalah dengan observasi sehingga tolak ukur peningkatan layanan didapatkan.

Merumuskan hal-hal yang harus ditingkatkan adalah dengan sistem aplikasi metode QFD sehingga aspek- aspek peningkatanan layanan dapat dirumuskan, dan berdasarkan aspek hubungan tersebutlah pihak manajemen perusahaan menentukan kebijakan perbaikan layanan konsumen.

\section{DAFTAR PUSTAKA}

Akao, Yoji, Shigeru Mizuno. (1994). QFD The Costumer-Driven Approach to Quality Planning and Development. Asian Productivity Organization Jepang.

Cohen, L. (1995). Quality Function Deployment: How To Make QFD Work For You. Addison Wesley Publishing Co.

Kotler, Philip. (1997). Manajemen Pemasaran Edisi Bahasa Indonesia. Jilid 1, Penerbit Prehallindo Jakarta.

Tjiptono Fandy, 2002, Manajemen Jasa, Edisi kedua, Cetakan ke 3, Penerbit Andi Yogyakarta

Tjiptono Fandy, 2002, Prinsip-Prinsip Total Quality Service, edisi kedua, penerbit Andi Yogyakarta.

Tjiptono Fandy, Diana Anastasia, 2002, Total Quality Manajemen, Edisi ke 4,Cetakan ke 2, Penerbit Andi Yogyakarta.

Walpole Ronald E, 1995, Pengantar Statistika, Edisi ke 3, PT. Gramedia Pustaka Utama, Jakarta.

A. Fauzi and E. Harli. Peningkatan Kualitas Pelayanan Melalui CRM dengan Metode. Jurnal Rekayasa Sistem dan Teknologi Informasi, 1(2017), $76-81$.

I. Kanedi, F. H. Utami and L. N. Zulita. Sistem Pelayanan untuk Peningkatan Kepuasan Pengunjung pada Perpustakaan arsip dan dokumentasi kota bengkulu. Jurnal Pseudocode, 1(2017),37-46. 